\title{
Phenology and recruitment of Caryocar costaricense (Caryocaceae), an endemic tree species of Southern Central America
}

\author{
Silvia Solís ${ }^{1,2}$, Jorge Lobo $^{1} \&$ Mayori Grimaldo ${ }^{1}$ \\ 1. Escuela de biología, Universidad de Costa Rica,2060 San José, Costa Rica; ssolism@oikos.unam.mx; \\ jorgelobosegura@gmail.com; mgrimaldo@gmail.com \\ 2. Centro de Investigaciones en Ecosistemas, Universidad Nacional Autónoma de México, Campus Morelia, Apartado \\ Postal 27-3 (Xangari), Morelia, Michoacán, C.P. 58089, México.
}

Received 20-XI-2008. C Corrected 22-II-2009. Accepted 25-III-2009.

\begin{abstract}
Basic aspects of the reproductive biology are largely unknown for most tropical tree species, although they are important elements to understand the impacts of anthropogenic activities as logging and forest fragmentation on these populations. In this study, data are presented on leaf and reproductive phenology, fruit production and seedling demography of a population of an endemic tree species of Southern Central America, Caryocar costaricense. This species has been affected by selective logging and forest fragmentation of its habitat. Phenology was studied by observation of 15-22 tree crowns during two reproductive periods (2003 and 2005). Circular plots were established around 11 adult trees to count the number of fallen fruits and seedlings during three years $(2003,2004,2005)$. Although reproductive phenology is restricted to the short dry season in this species, seed germination occurred year-round. Fruit and seedling production shows a strong inter-individual variation within the study populations, with two large trees producing nearly $50 \%-70 \%$ of the fruits and seedlings during two years. Most of the seeds that fall beneath the tree crown are covered by litterfall or removed by fauna. We found evidence that many of these seeds become part of a seed bank in the forest floor. Because of the observed reproductive dominance of few large trees in these populations, we propose that selective logging on reproductive trees can severely impact the recruitment of this species. Rev. Biol. Trop. 57 (3): 771-780. Epub 2009 September 30.
\end{abstract}

Key words: phenology, seed bank, Caryocar costaricense, demography, plant reproduction, tropical ecology, selective logging.

Fruit production, germination and juvenile survivorship (recruitment) are fundamentals in plant population demography dynamics. In natural populations of tropical tree species, high mortality in fruits and saplings, seed dispersion limitation and seedling recruitment limitation have been proposed as mechanisms that explain the high plant diversity and species distribution of these ecosystems (Harms et al. 2000, De Steven \& Wright 2002).

Phenological patterns in tropical plants are key factors in understanding their reproductive strategies, and therefore, fluctuations in resource availability that directly affect demographic dynamics and reproductive cycles in herbivores (Van Schaik et al. 1993). In canopy trees, phenology and reproduction are expected to be particularly important since they provide a significant resource of leaves, flowers and fruits. Recent studies indicate that phenology patterns are selected to optimize pollination, seed dispersion and seedling survivorship (Kudo 2006), and therefore, the study of plant phenology must be complemented with the study of seasonality of seedling recruitment, in order to understand the timing of flowering and fruiting.

Caryocar costaricense Donn. Sm. (Caryocaraceae) is an endemic species of the 
rain forests of Southern Central America. In the recent past this species has been submitted to selective extraction of the biggest individuals within remnant populations for commercial purposes (Lobo et al. 2007). The habitat of C. costaricense has been severely deforested, and the original distribution of the species is heavily fragmented (Lobo et al. 2007). Little is known about the reproductive strategy or demography of this species, aside from the obviously negative effects of logging on population recruitment (Lobo et al. 2007). The study of phenology and reproduction is particularly important to the conservation of this rare and endemic species.

The main objective of this work is to study some traits of the reproductive biology in $C$. costaricense. We narrowed the study to the following aspects: i) quantifying floral and fruit phenology, and estimating fruit production, ii) determining fruit fate and the seasonality of seedling recruitment dynamics in $C$. costaricense around mother trees, and iii) determining variation within populations and individuals in reproductive success over three consecutive reproductive phases. This information will help us to understand phenological patterns and the reproductive strategy of $C$. costaricense, as well as the impact of logging on population reproduction and recruitment

\section{MATERIALS AND METHODS}

Study site: the study was carried out in Finca El Remanso (8²3'11" N, 8378'26" W), $0-200 \mathrm{~m}$ above sea level, part of the Osa Wildlife Refuge, located in Osa Peninsula, South East Costa Rica. The Refuge covers ca 3000 ha, most of it mature tropical rain forest, soils predominantly ultisols. Annual total precipitation approaches $5000 \mathrm{~mm}$, with a less rainy season from January to March (50-150 mm monthly), a long rainy season from April to December (over $200 \mathrm{~mm}$ monthly), and the maximum monthly rain period from August to October (600-900 mm monthly). This site holds the most important population of $C$. costaricense, densities up to 4 trees per ha $>50 \mathrm{~cm}$ diameter at breast height (DBH)( Lobo et al. 2007).

Study species: $C$. costaricense is the only species from the family with a distribution outside South America. The Osa Peninsula holds the largest populations of this species (Sothers \& Souza 1999). There is one specimen reported in San Blas, north of Panama (Prance 1976), and none in Colombia (Herbario Nacional de Colombia, Herbario de Antioquía, unpublished).

An adult can reach the $50 \mathrm{~m}$ height and dbh range from $50-242 \mathrm{~cm}$. Flowers are yellow and hermaphroditic with 150 long stamens (Prance 1976), and have a strong garlic smell but once on the forest floor. Bat-pollination is assumed based on floral morphology, as reported for $C$. villosum and C. brasiliense (Gribel and Hay 1993, Martins and Gribel 2007). Fruit morphology is similar to $C$. amygdalyferum and $C$. brasiliense (Prance 1976), but smaller in size (6 $\mathrm{cm}$ diameter).

Phenology: Observations focused on the reproductive phase separated in the following categories: new leaves, floral buds, flowers, immature fruits and mature fruits. We quantified canopy cover for each category on a weekly basis from December to April over two years: $2002(n=15)$ and $2004(n=22)$. Observed individuals had a dbh $>20 \mathrm{~cm}$.

Fruit production, fate and seedling recruitment: In 2002 we located 11 reproductive trees in an area of 10 ha with non-overlapping crown area, to estimate fruit production, fruit fate and seedling recruitment. Trees were mapped and their dbh measured. We delimited a circular area of $20 \mathrm{~m}$ radius around each tree (twice the mean crown extension). The high height of the trees and dense canopy made it impossible to count fruits on the crown, therefore we used the amount of fruits fallen underneath the crown as an indirect measure of to the total number of fruits each tree produced. Fruits within this area include both fruits fallen straight from the canopy without secondary 
dispersion and fruits with limited dispersion. Few fruits were observed outside this area. We counted fallen fruits accumulated underneath the crown of each tree once a week during the fruit production period in 2003, 2004 and 2005. The highest amount of fallen fruits registered for each tree during one year was used as an indicator of annual fruit production. In 2005 we increased the sample with 10 trees to test variation between individuals within a year.

In 2003, 2004 and 2005 we marked a maximum of 60 fruits per tree that were monitored every week for two months after fruit ripening and subsequently every month for a year. In each census, we categorized the fate of the fruit as "present" if the fruit remained with the woody endocarp intact, "predated" if there were perforations on the woody endocarp, "not found" when the seed and mark disappeared from the forest floor, and "germinated" when we found emerged radicle and cotyledons. The true fate of seeds categorized as "not found" is unknown; the fruit could be predated, removed or just covered with litterfall in the same place.

During three consecutive reproductive episodes, from March 2003 to April 2005, we registered recruitment, mortality and growth for seedlings in the circular plots around trees. Each new seedling was marked and the distance from the closest adult measured. Growth was monitored until the end of the study. A census was carried out every four months.

Statistical analysis: We analyzed variation in fruit production between trees and years with generalized linear models (McCullagh \& Neder 1999). In the analysis, we used the logarithm of the maximum weekly fruit count in tree and year as dependent variable. Residual variation was modeled by a negative binomial distribution (White \& Bennetts 1996). Significance of effects was tested using the likelihood ratio test (LRT). To determine the effects of tree and year in fruit production we ran the former model with tree and year as independent variables. To determine the effect of dbh on fruit production we used the same model with $\mathrm{DBH}$ and $\mathrm{DBH}^{2}$ as independent variables.
Annual growth rate for each census was calculated as the difference between the first and the last measurement $(\mathrm{cm})$ divided by the number of days (expressed as fraction of a year) between the two measurements. Seedling abundance was expressed as the number of seedlings per tree. Monthly mortality rate was calculated for each census as the proportion of dead seedlings between one census and the previous $\left(\mathrm{M}=\mathrm{N}_{\mathrm{t}} / \mathrm{N}_{0}\right)$, and expressed as monthly mortality by the equation $\mathrm{m}=1-\exp (\ln (\mathrm{M}) / \mathrm{t})$, were " $\mathrm{m}$ " is monthly mortality rate and " $\mathrm{t}$ " is the number of months between census.

\section{RESULTS}

During phenological observations, we found that $C$. costaricense carried its flowers in an inflorescence with 30-35 flowers, but it might produce up to 60 flower buds. The inflorescences are exposed over the canopy, anthesis starts at 19:00 $\mathrm{hr}$ and 4-5 flowers per inflorescence open every night. The flowers stay in the canopy until the next morning. We also observed that mature fruits are dehiscent and exposed the yellow pulp over the canopy, presumably to attract fruit dispersers.

C. costaricense presents an annual phenological pattern. Reproduction occurs once during the dry season and is synchronized within the population. Trees have a deciduous phase at the beginning of the dry season, which lasts two weeks before the onset of the leaf flushing (Fig. 1). New foliage is completed in 10-30 days. Flower buds start to develop during the leaf flushing; therefore an individual can have vegetative and reproductive buds developing simultaneously. Flowering starts when the canopy is already fully covered with leaves, and lasts a month. In 2003 fruit development and ripening lasted 1.5-2 months, and the reproductive phase lasted until the end of April, at the onset of the rainy season. In 2005 the population was less synchronized in all the phenological phases, so at a population level the lapse of each phase was twice longer compared with that of 2003. The number of reproductive trees decreased and fruit development and ripening 

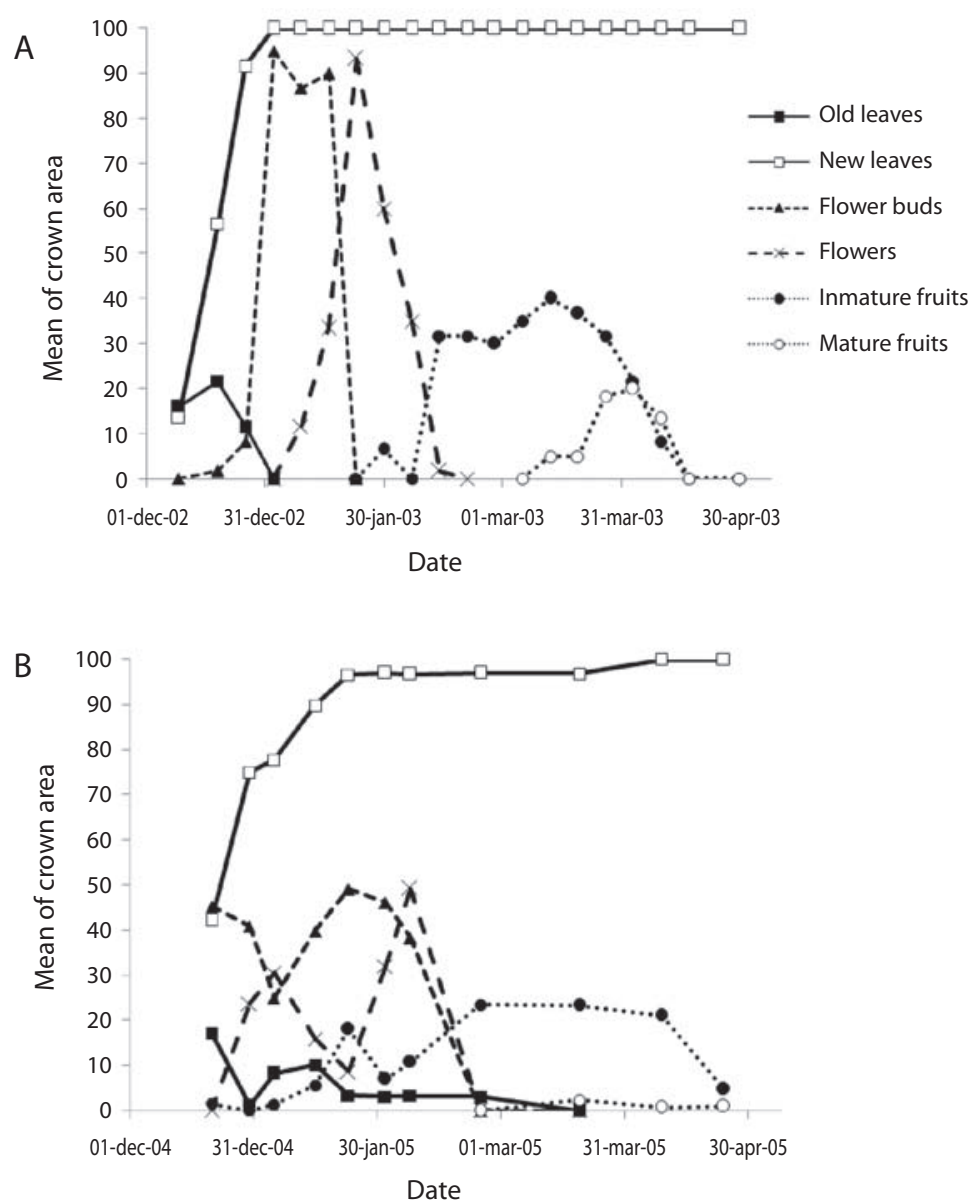

Fig. 1. Reproductive and leaf phenology of C. costaricense during the dry seasons of the years 2003 and 2005 , Osa Peninsula, Costa Rica. a. 2003. b. 2005. Y axis shows the mean percentage of the crown covered by leaves, flower buds, flowers, inmature fruits and mature fruits, obtained by averaging the respective percentages of the individual crowns in each date (ddmmyy).

lasted until the end of May, but total fruit production was less than in 2003. During the three years of study we registered two individuals that bloomed in isolation several months outside of the normal flowering time, the first in mid November 2003 and the second in July 2005.

There were no direct observations of fruit dispersal, but there was one sighting of a Red Macaw (Ara macao) eating immature fruits, and two sightings of female spider monkeys
(Ateles geofreoyii) with offspring, eating ripe fruits from the canopy. The female grabbed the fruits and dropped them inside the canopy after eating some of the pulp, so that the seed fell in the area beneath the crown.

Figure 2 describes fruit production in the study population, estimated by the maximum weekly fruit count in the circular plots. Fruit production was estimated for ten individuals in 2003, six in 2004 and twenty in 2005. Five individuals were observed for three years, 


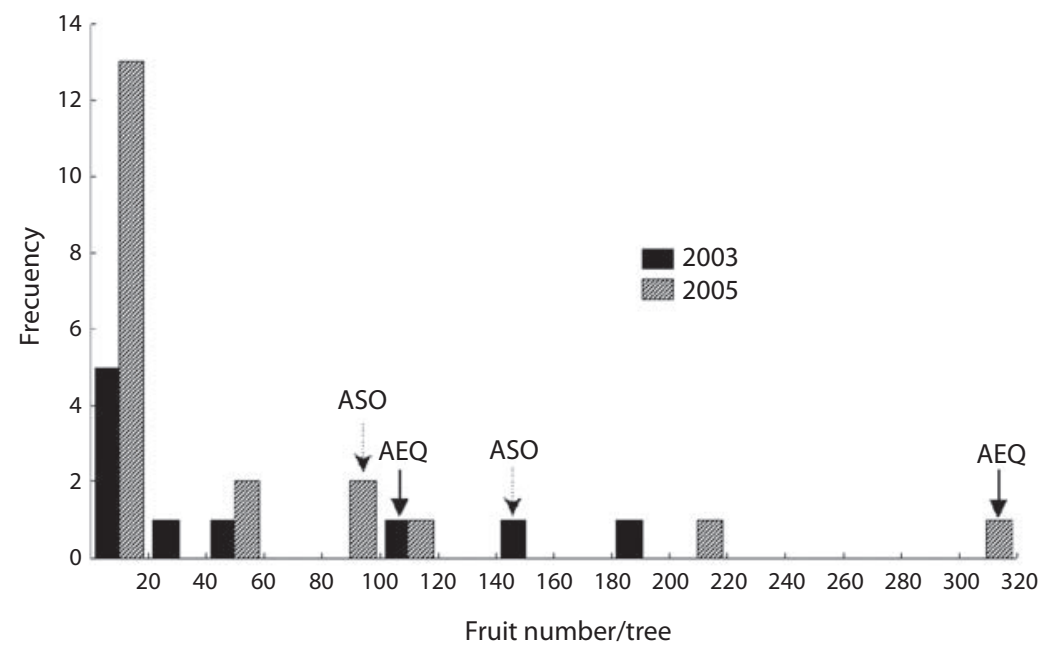

Fig. 2. Frequency distribution of the maximum fruit numbers found below C. costaricense crowns (20 m radius circular plots), during two reproductive periods (2003 and 2005). Fruit productions of two highly productive trees (AEQ and ASO) are indicated.

and three individuals were observed for two years, the others were observed only in 2005 . Considering only the years with larger sample sizes (2003 and 2005), variation in fruit production between individuals was higher in 2005 (Coefficient of Variation $(\mathrm{CV})=169.6$ ), compared to $2003(\mathrm{CV}=129)$. In 2005 we found no fruits in the plot area in $30 \%$ of the study population, while in the same year we registered the highest fruit counts for the whole study from a single tree. Including only individuals with more than one year of observations, regression analysis showed a significant effect for tree $(\mathrm{LRT}=27.75$; degrees of freedom $(\mathrm{df})=7 ; \mathrm{p}<$ 0.001 ) but not for year (LRT $=1.42 ; \mathrm{df}=2 ; \mathrm{p}$ $=0.4919$ ) in fruit production. In 2003 two trees contribute with $72 \%$ of the fruits, while in 2005 two trees produced $53.6 \%$ of the fruits of the year. Two individuals showed a high fruit output during three consecutive reproductive episodes (Fig. 2). Tree size (measure as dbh) had a significant effect on fruit production. The study population has an average dbh of $123.9 \pm 39.42$ $\mathrm{cm}$, with a range of $37.0-242.0 \mathrm{~cm}$. Figure 3 shows the regression curve given by equation $y=-0.95+0,03 x-0,0001 x^{2}$, that explains the relation of tree size and fruit output $\left(\mathrm{R}^{2}=0.30\right.$, $\left.\mathrm{F}_{2,33}=6.98, \mathrm{P}<0.01\right)$. The regression analysis showed a decrease in fruit production with increasing tree size, and predicts that no fruits are produced by trees smaller than $30 \mathrm{~cm}$ dbh.

In year 2003 we marked 260 fruits (mature and immature) from eleven trees, and in 2004, 157 fruits from six trees. We determine the fate of the seeds one year after the reproductive event. In 2003 and 2004 seed germination rate was $1.5 \%$ and $1.9 \%$, respectively. Most of the seeds fell in the category "not found", $80 \%$ in 2003 and $53.5 \%$ in 2004 , and they were probably covered by litterfall or removed by fauna. Predation occurred in 10.4\% (2003) and 14.6\% (2004) of the seeds, with distinguishable marks of mammals or insects. After one year we found that the percentage of seeds that remained intact on the forest floor was $8.1 \%$ in 2003 and $29.9 \%$ in 2004. More seeds were lost in 2003, and more seeds remained intact in the same place in 2004. To determine viability of seeds that remained on the floor, we collected 15 fruits (endocarp + seed) and planted them in a greenhouse close to the study area. We obtained $50 \%$ of germination in the first two weeks. 


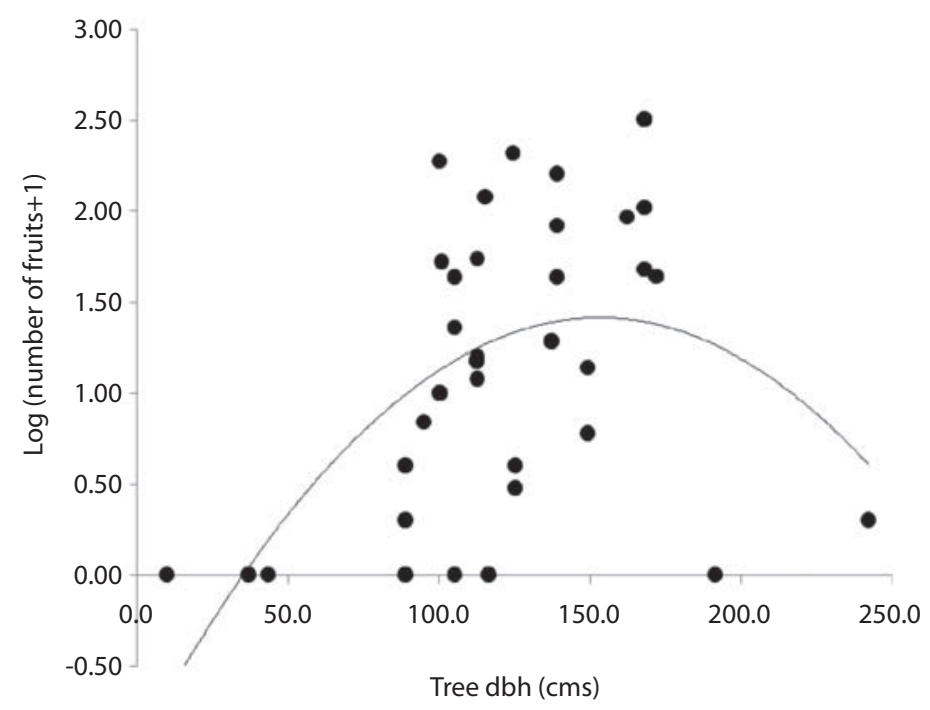

Fig. 3. Relationship between tree dbh and the logarithm of maximum fruit number found below crown in 36 C. costaricense trees observed during three years. Curve represents the fitted equation $y=-0.95+0.03 x-0.0001 x^{2}$.

During three years of study, we marked a total of 304 seedlings from 7 mothers. Figure 4 shows the variation in seedlings density, recruitments and mortality for each census. Seedling establishment occurs both in the dry and rainy seasons, and increases with light gaps, as occurred in the period December 2003-March 2004, when a tree fell next to one of the mothers with high fruit production. This event became the most important seedling establishment during the study period, in one census contributing $57 \%$ of the total seedling sample for all trees. In this tree, seed germination continued for several months and as a result contributed to $50 \%$ of the total seedling germination in the population. Monthly mortality rate oscillated between 2 and $10 \%$ in most of the census, but it increased in April $2004(\approx 20 \%)$, at the end of the dry season. The average monthly mortality rate resulted in an annual mortality rate of $50 \%$ for seedlings during the first year of establishment. The average lifespan for the seedlings in the study was 48-590 days, the upper limit is given by the observation time at the end of the study. The range in size for the seedlings was 4.2-122.3 $\mathrm{cm}$, with an average annual growth rate of $11.3 \mathrm{~cm} /$ year $(\mathrm{SD}=30.3)$. We observed some individuals that produced negative values in growth rates; damaged or broken seedlings that trim their height, but after several censuses reestablished their size. For six adult trees where fruit production and seedling establishment were observed during three consecutive years, relation between these two variables was low (Pearson $\mathrm{r}=0.09, \mathrm{P}>0.05$ ). This result shows that plant density in the sample area is barely influenced by the number of seeds produced in a previous reproductive event.

\section{DISCUSSION}

Phenology and recruitment: The reproductive phases in the phenology of $C$. costaricense are constrained to the dry season in the study site, a trait shared by many other tree species from the seasonal rain forest in the SE 


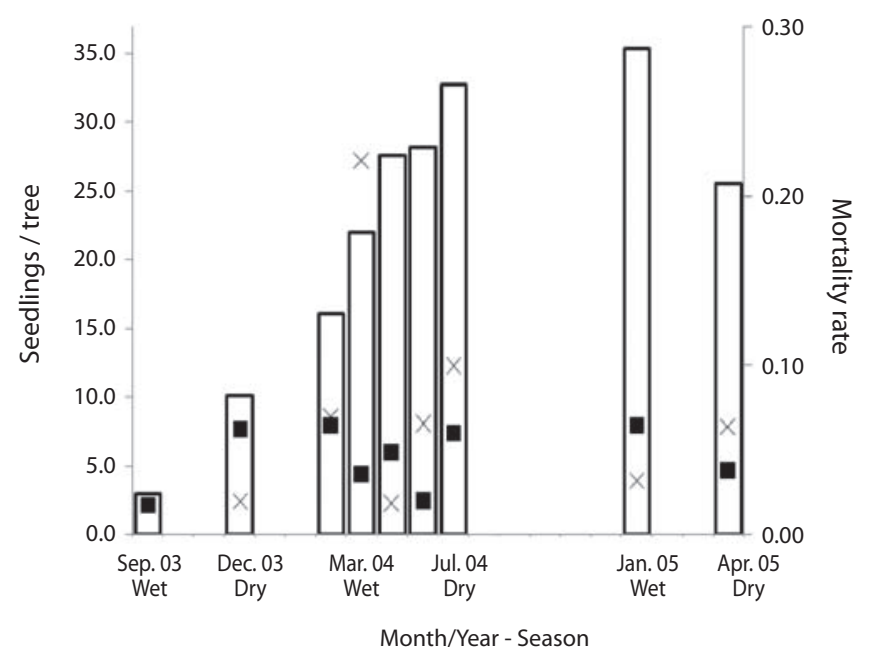

Fig. 4. Population dynamics of $C$. costaricense seedlings in the area beneath the crowns of 7 adult trees (20 m radius circular plots). Open bars indicate the mean number of seedlings per tree in each date, squares are the mean number of new seedlings per tree and $\mathrm{X}$ indicate the monthly mortality rate (right axis) based on the number of seedlings death in the interval before the date.

of Costa Rica (Lobo et al. in press). C. costaricense, however, would be part of a small group of species in this habitat that exhibit a deciduous phase coinciding with flowering and fruiting (Frankie et al. 1974). In C. costaricense the deciduous phase is short and finished before the flowering phase was completed. We found variation between years in the synchronization of phenological phases. On the other hand, seedling establishment was not seasonal like some previously studied tropical tree species (De Steven \& Wright 2002), because seedling germination occurs year-round. Seedling mortality rate in the first year beneath tree crowns is high in C. costaricense, like many other tropical tree species (Augspurger 1984), but we did not find evidence for a density dependent effects in mortality, since there was no rise in mortality in 2004, the year with the highest density of seedlings in the population.

Fruit production shows a strong variation within the study population. In the circular plots below tree crowns a large fraction of the trees (including the ones with the largest $\mathrm{dbh}$ ) showed very low levels of fruit production, and few individuals produced most of the fruits for three consecutive years. Although this estimation is based on fruits below tree crowns, we assumed this data is highly correlated with total tree fruit production. In $C$. costaricense the trees with high fruit output seems to dominate the reproduction at a population level during several reproductive episodes, as observed in other tree species in temperate (McCarthy \& Quinn 1989) and tropical zones (De Steven \& Wright 2002). A high and wide tree crown, characteristics correlated with the tree dbh, could partially explain its reproductive dominance, although we also register two large-crowned trees with low fruit output. Reproductive dominance by few individuals occurs also in seedling establishment. Seedling density was concentrated in one of the trees with high fruit production, and is likely the result of high fruit output accumulated for more than one year and the sudden creation of a light gap next to it. These results suggest that the seedling recruitment rate could be limited by seed production and seedling establishment (De Steven \& Wright, 2002). 
Seed bank: Most of the seeds that fell beneath the tree crown did not stay in place for very long, and a very low percentage of seeds germinated the year after deposition. Although predation or secondary dispersion might be the cause for these results, the seeds also could be buried by litterfall or dirt in the surface of the ground, preventing or delaying germination. The mass germination of seeds that were neither previously marked nor visible, after the creation of the light gap, suggest that a high proportion of the seeds "not found" are becoming part of a seed bank latent in the forest floor close to the mother tree (Vázquez-Yanes \& Orozco-Segovia 1984, Garwood 1989). A physical dormancy might be facilitated by the existence of a hard exocarp (Baskin \& Baskin 1989) as observed in C. brasiliense (Araujo 1994, Dombroski et al. 1998). The woody endocarp that encloses the seeds turned out to be very resistant to water, fungus and insects that would otherwise eat the oily pulp leaving the spiny endocarp intact. This resistance trait was evident in the germination success from the sample of seeds collected after remain one year in the forest floor. Additional support for the theory of the existence of a seed bank in $C$. costaricense is the continuous establishment of seedlings all year round, even in dates far from the fructification season. Other tropical tree species like Manilkara bidentata (Forget et al. 2001) report delayed germination, and Bertholletia excelsa seeds remain in the forest floor at least one year until the outer parts of the fruit completely disappear (Zuidema $\&$ Boot 2002). The existence of a seed bank accumulating cohorts of seeds from several years could explain the low correlation between fruit production and seedling establishment found in this population, but further study is needed to describe the dynamics of the seed bank including maximum lifetime of the seeds on the forest floor.

Logging effects: The results obtained from fruit production and seedling establishment suggest that some adult trees, mainly in the $80-120 \mathrm{~cm}$ DBH size classes, dominate the seed output in the population. The same trend is observed in the amount of seedlings established in the area beneath the tree crown. It is possible that the same trend of reproductive dominance occurs in distances farther from the mother tree, if the distance of dispersion is correlated with fruit production. On the other hand, seedlings are not very abundant in $C$. costaricense populations, and the groups of seedlings are restrained to the neighborhood surrounding the mother trees. If this would be the rule for the species reproductive strategy, selective logging on the reproductive size class is provoking a severe impact on the recruitment of individuals for maintenance of the species. The impact may be even stronger than that predicted by models assuming that fertility is constant or randomly distributed among adult individuals and only influenced by tree diameter (Gourlet-Fleury et al. 2005, Degen et al. 2006). Lobo et al. (2007) demonstrated that selective logging produces a decrease in seedling establishment compared to areas with similar adult density but not disturbed by this activity, and the condition remains even 5 years after the extraction. Data from this study suggests that one possible cause of the deficiency in seedlings for a prolonged time is the incidental extraction of highly reproductive adults within the population. The construction of logging roads can also contribute to a decrease in seedling populations by soil compaction and erosion, which can reduce the seed bank near logged trees.

\section{ACKNOWLEDGMENTS}

We are thankful to Joel Stewart, Belém Momeñe and El Remanso Resort for valuable support and acces to Osa Wildlife Reserve. We thank E. Chacón, G. Saborío, M. Fernández, R. Salas, M. Solís and El Remanso staff for field assistance. This study was financially supported by a Thesis scholarship from Consejo Nacional para Investigaciones Científicas y Tecnología (CONICIT) to S. Solís, an Idea Wild granted to S. Solís, and a Universidad de Costa Rica Research Grant to J.Lobo. (No. 111-A3-525) . 


\section{RESUMEN}

Los aspectos básicos de la biología reproductiva de árboles tropicales son en su mayoría desconocidos, aunque son conocimientos esenciales para entender el impacto de actividades antropogénicas como la tala selectiva y la fragmentación de bosques. En este estudio se presentan datos sobre la fenología foliar y reproductiva, la producción de frutos, y la demografía de plántulas de una población de Caryocar costaricense, una especie endémica del sur de América Central, afectada por tala selectiva y fragmentación de su hábitat original. La fenología fue estudiada por medio de la observación de las copas de 15 a 22 árboles adultos durante dos períodos reproductivos (años 2003 y 2005). Para estudiar la caída de frutos y la dinámica de germinación y supervivencia de plántulas, se establecieron parcelas circulares alrededor de 11 individuos adultos, donde se realizaron observaciones durante tres años $(2003,2004,2005)$. Aunque la fenología reproductiva está limitada a la corta estación seca local, la germinación de semillas se da todo el año. La producción de frutos y plántulas mostró una alta variación inter-individual, con dos árboles produciendo $50-70 \%$ de todos los frutos y plántulas durante dos años. La mayoría de las semillas que caen bajo la copa son cubiertas por mantillo o removidas por la fauna. Muchas de estas semillas se vuelven parte de un banco de semillas latente en el piso del bosque. Debido a la dominancia reproductiva de unos pocos grandes árboles en estas poblaciones, se propone que la tala selectiva sobre individuos reproductivos puede provocar un impacto severo sobre el reclutamiento de nuevos individuos en estas poblaciones

Palabras clave: fenología, banco de semillas, demografía, reproducción de plantas, ecología tropical, tala selectiva.

\section{REFERENCES}

Araujo F.D. 1994. The ecology, ethnobotany and management of Caryocar brasiliense Camb. around Montes Claros, MG, Brasil. Oxford, Oxford, England.

Augspurger C.K. 1984. Seedling survival of tropical tree species: interactions of dispersal distance, light-gaps, and pathogens. Ecology 65: 1705-1712.

Baskin J.M \& C.C. Baskin. 1989: Physiology of dormancy and germination in relation to seed bank ecology, p.53-66. In M.L Leck, V.T. Parker \& R.L. Simpson (eds.). Ecology of soil seed banks. Academic, London, England.

Degen B., L. Blanc, H. Caron, L. Maggia, A. Kremer \& S. Gourlet-Fleury. 2006. Impact of selective logging on genetic composition and demographic structure of four tropical tree species. Biol. Cons.: 386-401.

De Steven D. \& S.J. Wright. 2002. Consequences of variable reproduction for seedling recruitment in three neotropical tree species. Ecology 83: 2315-2327.

Dombroski J.L.D., R. Paiva \& I.P. Camargo. 1998. Efeito da escarificação sobre a germinação do pequizeiro (Caryocar brasiliense Camb.). Rev. Bras. Fruticultura, Cruz das Almas 20: 68-73.

Forget P., J.M. Rankin-de Merona \& C. Julliot. 2001. The effects of forest type, harvesting and stand refinement on early seedling recruitment in a tropical rain forest. J. Trop. Ecol. 17: 593-609.

Frankie G., H.G. Baker. \& P.A. Opler. 1974. Comparative phenological studies of trees in Tropical wet and dry forests in the lowlands of Costa Rica. J. Ecol. 62: 881-899.

Garwood N.C. 1989. Tropical soil seed banks: a Review, p.149-210. In M.L Leck, V.T. Parker \& R.L. Simpson (eds.). Ecology of soil seed banks. Academic, London, England.

Gribel R. \& J.D. Hay. 1993. Pollination ecology of Caryocar brasiliense (Caryocaraceae) in Central Brazil cerrado vegetation. J. Trop. Ecol. 9: 199-211.

Gourlet-Fleury S., G. Cornu, S. Jésel, H. Dessard, J. Jourget, L. Blanc \& N. Picard. 2005. Using models to predict recovery and assess tree species vulnerability in logged tropical forests: a case study from French Guiana. Forest Ecol. Manag. 20: 69-86

Harms K.E., S.J. Wright, O. Calderón, A. Hernández \& E. Allen-Herre. 2000. Pervasive density-dependent recruitment enhances seedling diversity in a tropical forest. Nature 404: 493-495.

Kudo G. 2006. Flowering phenologies of animal-pollinated plants: reproductive strategies and agents of selection, p. 139-158. In L.D. Harder \& S. C. Barrett (eds). Ecology and Evolution of Flowers. Oxford, Oxford, England.

Martins R.L. \& R. Gribel. 2007. Polinização de Caryocar villosum (Aubl.) Pers. (Caryocaraceae) uma árvore emergente da Amazônia Central. Rev. Bras. Bot. 30: $37-45$.

McCullagh P. \& J.A. Nelder. 1999. Generalized Linear Models. Chapman \& Hall, London, England. 
McCarthy B.C. \& J.A. Quinn. 1989. Within and amongtree variation in flower and fruit production in two species of Carya (Juglandaceae). Am. J. Bot. 76: 1015-1023.

Lobo J., G. Barrantes, M. Castillo, R. Quesada, T. Maldonado, E. Fuchs, S. Solís y M. Quesada. 2007. Effects of selective logging on the abundance, regeneration and short-term survival of Caryocar costaricense (Caryocaceae) and Peltogyne purpurea (Caesalpinaceae), two endemic timber species of southern Central America. Forest Ecol. Manag. 245: $88-95$.

Prance G.T. 1976. Caryocaraceae, p. 541-546. In R.E. Woodson y R.W. Shery (eds.) Flora of Panama. Missouri Botanical Gardens, Missouri, USA.

Sothers C.A. \& M.A.D. de Souza. 1999. Caryocaraceae, p. 236-237. In J.E.L.S. Ribeiro (ed.) Flora da Reserva Ducke: Guia de identificação das plantas vasculares de uma floresta de terra-firme na Amazônia Central.
Instituto Nacional de Pesquisas da Amazônia, Manaus, Amazonas, Brazil.

White G.C. \& R.E. Bennetts. 1996. Analysis of frequency count data using the negative binomial distribution. Ecology 77: 2549-2557.

Van Schaik C.P., J.W. Terborgh \& S.J. Wright. 1993. The phenology of tropical forests: adaptive significance and consequences for primary consumers. Ann. Rev. Ecol. Syst. 24: 353-377.

Vázquez-Yanes C \& A. Orozco-Segovia. 1984. Ecophysiology of seed germination in the tropical humid forests of the World: A review, p.37-50. In E. Medina, H.A. Mooney, \& C. Vázquez-Yanes (eds.). Physiological ecology of plants in the wet tropics. Junk, The Hague, Holland.

Zuidema, P.A. \& R.G.A. Boot. 2002. Demography of the Brazil nut tree (Bertholletia excelsa) in the Bolivian Amazon: impact of seed extraction on recruitment and population dynamics. J. Trop. Ecol. 18: 1-31. 